\title{
Review
}

\section{Goniothalamus Species: A Source of Drugs for the Treatment of Cancers and Bacterial Infections?}

\section{Christophe Wiart}

\author{
School of Pharmacy, The University of Nottingham (Malaysia Campus), Jalan Broga, 43500 Semenyih, \\ Selangor, Malaysia
}

\begin{abstract}
Irrespective of the presence of cytotoxic acetogenins and styryl-lactones in the genus Goniothalamus, only 22 species in the genus Goniothalamus, out of 160 species (13.7\%) have so far been investigated. In an effort to promote further research on the genus Goniothalamus which could represent a source of drugs for the treatment of cancers and bacterial infections, this work offers a broad analysis of current knowledge on Goniothalamus species. Therefore, it includes (i) taxonomy (ii) botanical description (iii) traditional medicinal uses and (iv) phytochemical and pharmacological studies. We discuss the molecular mechanisms of actions of acetogenins and styryl-lactones, with some emphasis on the possible involvement of protein kinase, Bax and TRAIL receptors in the cytotoxic effects of styryl-lactones. We also report (v) the growth inhibition of several nosocomial bacteria by Goniothalamus. scortechinii. The crude methanol extract of G. scortechinii showed a good and broad spectrum of antibacterial activity against both Gram-negative and Gram-positive bacteria.
\end{abstract}

Keywords: acetogenins - antibacterial-antifungal-apoptosis - cytotoxic-foodborn bacteriaGoniothalamus-Goniothalamus scortechinii-nosocomial-styryl-lactones.

\section{Introduction}

The genus Goniothalamus Hk. f. et Thoms. (Family Annonaceae A.L. de Jussieu 1789 nom. conserv., the Custard-Apple Family) consists of 160 species of archaic shrubs and treelets which grow in the shady primary rainforest of tropical Asia. These plants can be quickly spotted in field collection by their aromatic bark and fusiform leathery flowers $(1,2)$. A number of Goniothalamus species have been used for timber, as fiber sources (2), for ornamental and medicinal purposes, especially in relation with post-partum and abortion $(3,4)$. The genus Goniothalamus belongs to a primitive taxon of flowering plants: the Annonaceae (Family Annonaceae A.L. de Jussieu 1789 nom. conserv.,

For reprints and all correspondence: Dr C. Wiart, School of Pharmacy The University of Nottingham (Malaysia Campus), Jalan Broga, 43500 Semenyih, Selangor, Malaysia. Tel: +60-3-79675749;

Fax: +60-3-79674964; E-mail: christophe_wiart@yahoo.com the Custard-Apple Family) (5). The Annonaceae form a large, generally recognizable family of about 122 genera and 2000 plant species which are widespread chiefly in tropics and subtropics (6-8). In regards to the pharmacological potentials of Goniothalamus species, there is a massive body of evidence to suggest that this taxon has the ability to elaborate series of acetogenins and styryllactones which are cytotoxic against a broad array of cancer cells including breast, colon, kidney and pancreatic carcinoma cells. Interestingly, both acetogenins and styryl-lactones are completely different in terms of chemical structure but their cellular activities are involving the same organelles in mammals: the mitochondria. An exciting fact about the mode of action of styryllactones, which is still an enigma, is their possible action via protein kinase and TRAIL receptors. In an effort to promote further research on the genus Goniothalamus which could be a promising source for chemotherapeutic agents, this work offers a broad analysis of current knowledge on Goniothalamus species. We also highlight 
the antibacterial activity of Goniothalamus scortechinii. This is the first antibacterial study report on Goniothalamus species.

\section{Botanical Description}

The botanical characteristics of Goniothalamus species are homogenous and simple. When searching for Goniothalamus species in the rainforest, one is advised to look for few-leaved slender treelets or shrubs with smooth, thin and fibrous and strongly aromatic bark and upright blackish cylindrical trunk. The leaves are few, simple, alternate and exstipulate. The blade is glossy, oblong - lanceolate to obovate and thick. The secondary nerves are oblique, conspicuous, straight and parallel with scalariform reticulations (9). The flowers are axillary and characteristically woody, often dark green and fusiform (Fig. 1). The calyx consists of three sepals which are valvate, membranous, veined, free or connate. The corolla consists of two series of three petals which are veined and coriaceous, the inner smaller and fused in a vault above the androecium. The outer petals are marked with a prominent midrib. The androecium comprises several stamens which are linear and oblong. The gynaecium consists of several free carpels grooved at the anterior side. The fruits are stalked or sessile one to two seeded ripe carpels (6). The geographical pattern of distribution of this genus suggests the genus Goniothalamus to have been among the flowering plants to have colonized hearth during the post-Permian early Cretaceous time.

\section{Traditional Medicinal Uses}

Out of 160 species, five Goniothalamus species are medicinal. These have been used in traditional medicinal Asian system, and since a long period of time most of these in connection with abortion, childbirth and fever (10). The leaves of G. macrophyllus Hook.f \& Thoms. are used to allay fever and a decoction of the roots is given as a post-partum remedy and to cause abortion (3). In Malaysia, a decoction of leaves is used externally to allay fever (3). The roots of G. giganteus Hook.f \& Thoms. are used to abort and treat colds and the heated leaves are applied onto swellings (10). A decoction of G. scortechinii is given as a post-partum protective remedy (3). The roots of G. tapis Miq. are used as abortifacient during early months of pregnancy (3). In Java, Indonesia, an infusion of the roots is used to treat typhoid fever (11). In Taiwan, the seeds of G. amuyon Merr. are used to treat scabies (12). In the Philippines, the seeds are used to treat rheumatism and tympanites, and the fruit is stomachic (4). None of the traditional uses previously mentioned has been substantiated yet via strict pharmacological experimentation. However, these species have been studied for their chemical constituents.

\section{Phytochemical and Pharmacological Studies}

\section{General Concept}

Twenty-two species (13.7\%) in the genus Goniothalamus, out of 160 species, have so far been phytochemically investigated namely: $G$. amuyon, $G$. andersonii J.Sincl., G. arvensis Scheff, G. borneensis Mat-Salleh, G. cardiopetalus, G. cheliensis. Hu, G. donnaiensis Finet \& Gagnep., G. gardneri Hook. f. \& Thoms., G. giganteus Hook. f. \& Thoms., G. griffithii Hook.f. \& Thoms., G. howii Merr., G. leiocarpus (W.T.) Wang P.T. Li, G. malayanus Hook. f. \& Thoms., G. marcanii Craib, G. montanus J. Sincl., G. scortechinii, G. sesquipedalis Hook. f. \& Thoms., G. tapis Miq., G. thwaitesii Hook. f. \& Thoms., G. umbrosus J. Sincl., G. uvaroides King and G. velutinus Airy Shaw. These phytochemical studies have resulted so far in the isolation of two very distinct classes of lipophilic secondary metabolites: acetogenins and styryl-lactones, both of them possessing complex stereochemistry and existing in different stereoisomeric forms (13). Testing of these chemicals for cytotoxicity showed that both acetogenins and styryl-lactones are toxic for several human tumors cell lines. Note that both acetogenins and styryl-lactones are cytotoxic for mammalian cells as the result of distinct biochemical pathways which however take both their molecular origin near or in the mitochondrial membrane and or mitochondrial respiratory system (14). To date some evidence clearly demonstrate that acetogenins have beneficial effects against the growth of tumors, including ovarian tumors (15), gastric tumors (16) and multidrugresistant cancerous xenografts (17) via the activation of caspases enzymatic cascades (18). Most phytochemical reports found so far on Goniothalamus species deal with the chemical constituents of a medicinal species: G. giganteus which abounds with cytotoxic acetogenins (Table 1) as mentioned further.

\section{Acetogenins: Unusual Polyketides}

Acetogenins are unusual series of polyketides which have so far only been characterized from members of the family Annonaceae including in the genus Goniothalamus particularly G. giganteus, G. donnaiensis and G. gardneri $(9,10)$. In the genus Goniothalamus, acetogenins were first characterized as the active principles responsible for shrimp lethality from the bark of G. giganteus collected from Thailand. Extract of the bark showed toxicity in the brine shrimp test and showed murine cytotoxicity in the 3PS (P388) leukemia bioassay. The cytotoxicity of this extract compelled a series of phytochemical studies which 


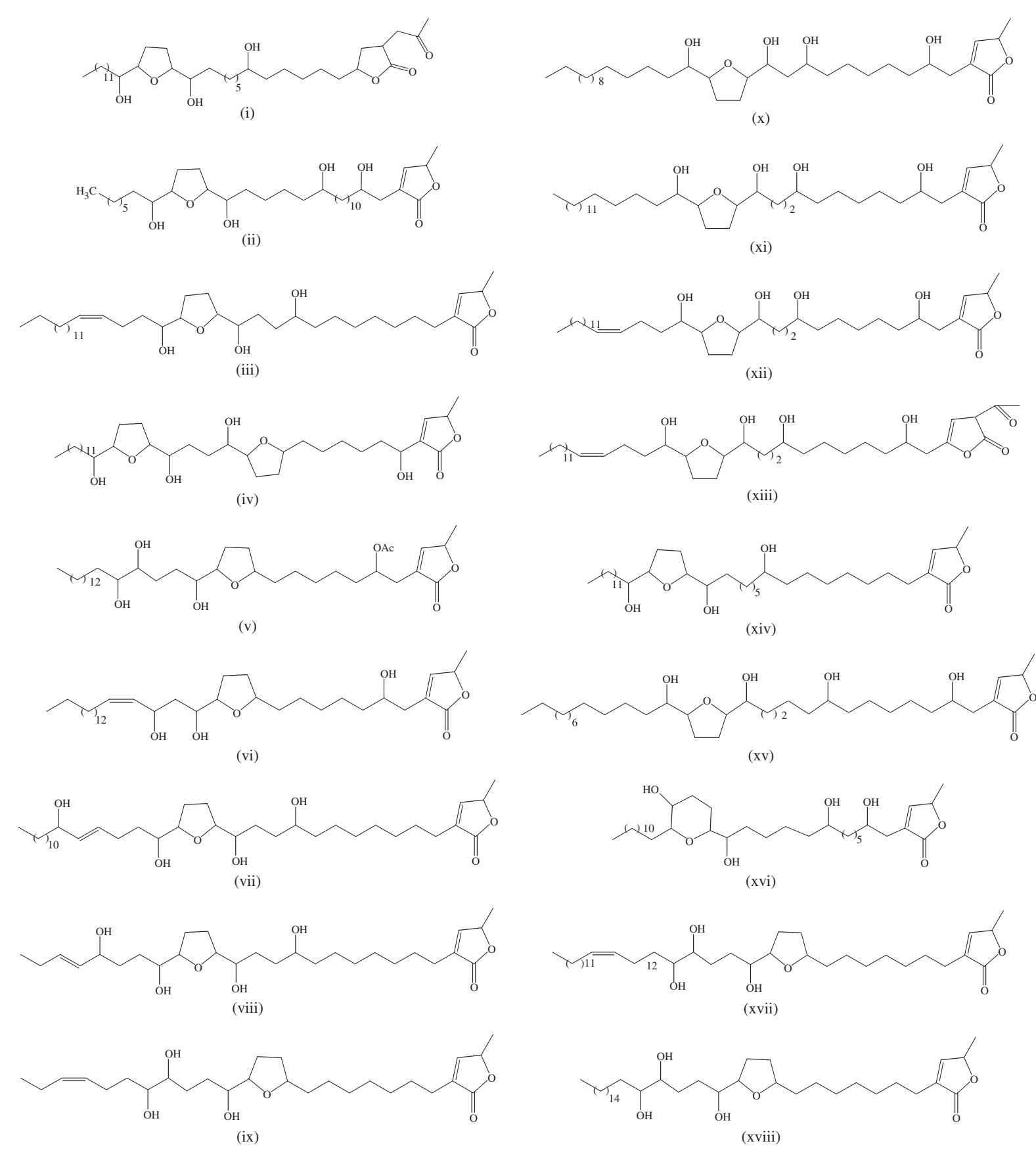

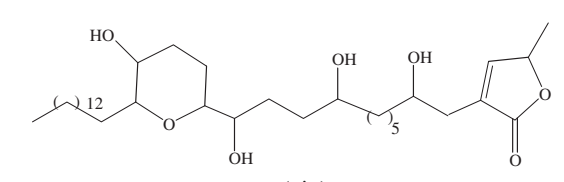

(xix)

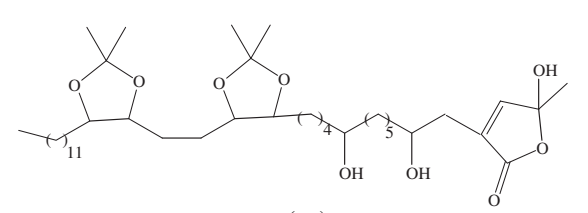

(xx)
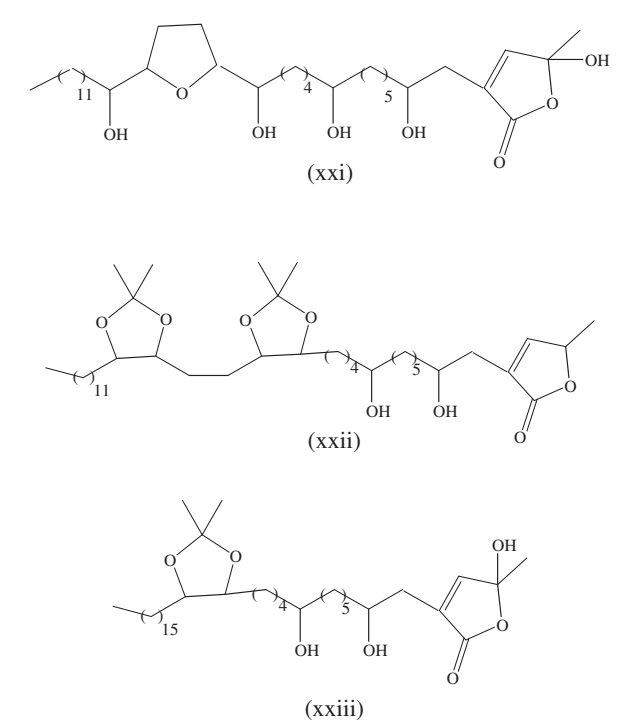

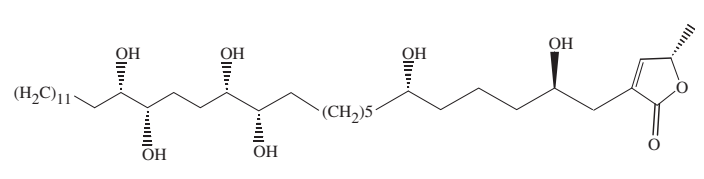

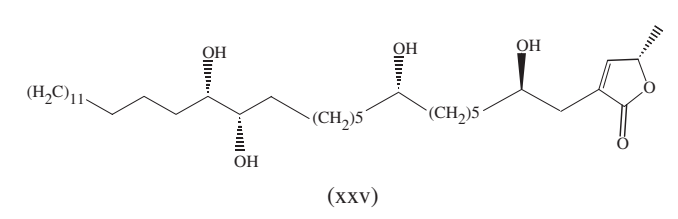


Table 1. Antitumor activity of Goniothalamus species

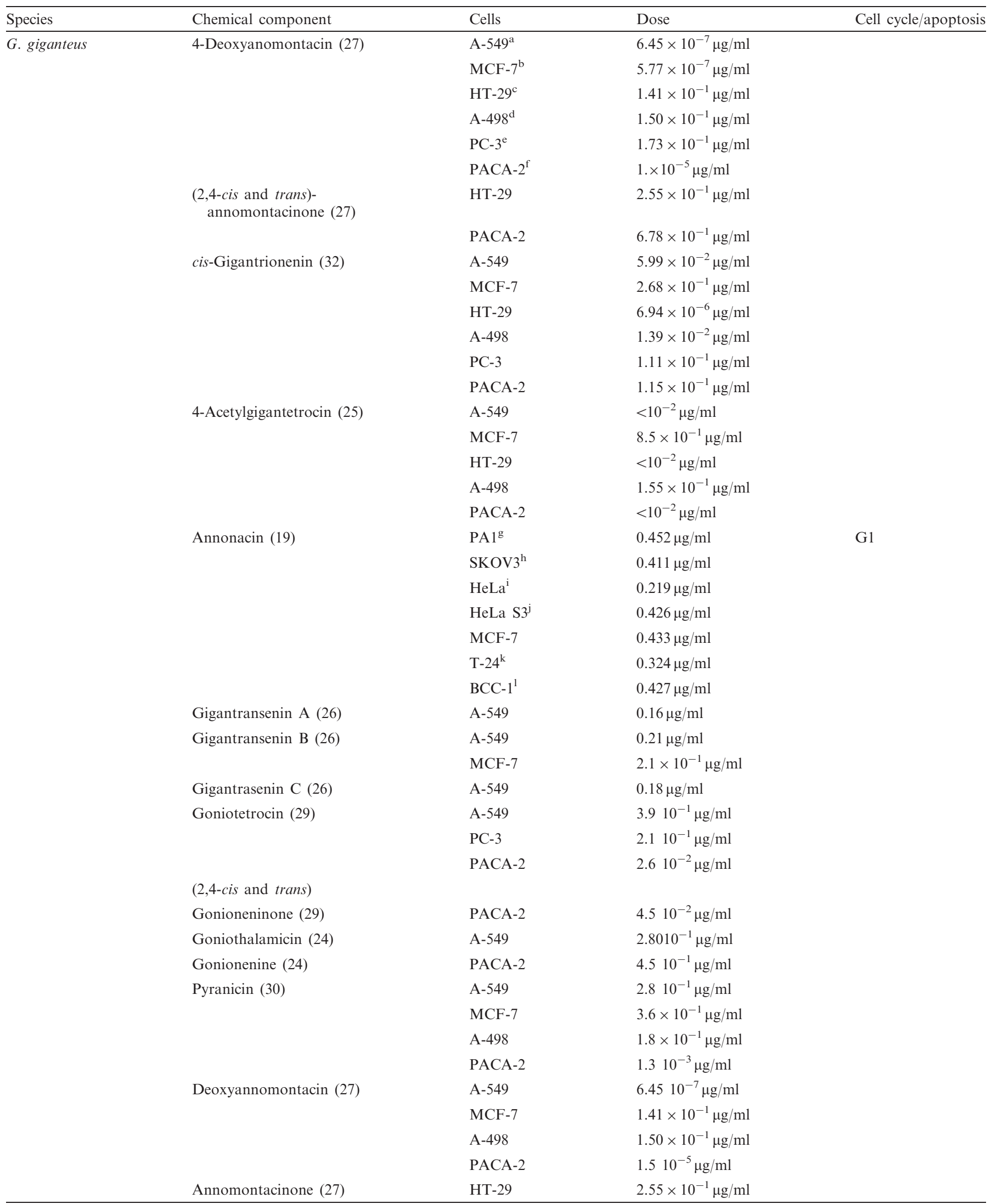


Table 1. Continued

\begin{tabular}{|c|c|c|c|c|}
\hline Species & Chemical component & Cells & Dose & Cell cycle/apoptosis \\
\hline \multirow[t]{9}{*}{ G. giganteus } & Annomontacinone (27) & PACA-2 & $6.78 \times 10^{-1} \mu \mathrm{g} / \mathrm{ml}$ & \\
\hline & Pyragonicin (30) & A-549 & $<10^{-2} \mu \mathrm{g} / \mathrm{ml}$ & \\
\hline & & A- 498 & $1.55 \times 10^{-1} \mu \mathrm{g} / \mathrm{ml}$ & \\
\hline & & PACA-2 & $5.810^{-3} \mu \mathrm{g} / \mathrm{ml}$ & \\
\hline & Goniotrionin (30) & A-549 & $7.710^{-3} \mu \mathrm{g} / \mathrm{ml}$ & \\
\hline & & MCF-7 & $5.310^{-6} \mu \mathrm{g} / \mathrm{ml}$ & \\
\hline & & A-498 & $2.10^{-3} \mu \mathrm{g} / \mathrm{ml}$ & \\
\hline & & PC-3 & $3.610^{-1} \mu \mathrm{g} / \mathrm{ml}$ & \\
\hline & & PACA-2 & $5.410^{-3} \mu \mathrm{g} / \mathrm{ml}$ & \\
\hline G. donnaiensis & Goniodonin $(34,35)$ & HCT- $8^{\mathrm{m}}$ & $<10 \mu \mathrm{g} / \mathrm{ml}$ & \\
\hline G. gardneri & Gardnerilin B (37) & $\operatorname{Bel} 7402^{\mathrm{n}}$ & $8.5 \mu \mathrm{g} / \mathrm{ml}$ & \\
\hline \multirow[t]{2}{*}{ G. andersonii } & Goniothalamin (47) & $\mathrm{HL}-60^{\circ}$ & & apoptosis \\
\hline & & Jurkat $\mathrm{T}^{\mathrm{p}}$ & & apoptosis \\
\hline \multirow[t]{6}{*}{ G. griffithii } & Goniothalamin (82) & HepG2 & $8.83 \mu \mathrm{M}$ & G2/apoptosis \\
\hline & & HepG2R & $8 \mu \mathrm{M}$ & \\
\hline & Altholactone (82) & HepG2 & $0.7 \mu \mathrm{M}$ & apoptosis \\
\hline & & HepG2R & $6.17 \mu \mathrm{M}$ & \\
\hline & Goniodiol (82) & HepG2 & $10 \mu \mathrm{M}$ & G2 \\
\hline & & HepG2R & $8.33 \mu \mathrm{M}$ & \\
\hline \multirow{2}{*}{ G. cheliensis } & & HCT-8 & $4.43 \mu \mathrm{M}$ & \\
\hline & & KB & $7.23 \mu \mathrm{M}$ & \\
\hline \multirow[t]{2}{*}{ Synthesized } & Goniothalamin (66) & MCF-7 & $10.5 \mu \mathrm{M}$ & \\
\hline & & HT-29 & $11.2 \mu \mathrm{M}$ & \\
\hline
\end{tabular}

ahuman lung carcinoma; ${ }^{b}$ human breast carcinoma; ${ }^{c}$ human colon adenocarcinoma; ${ }^{\mathrm{d}}$ human kidney carcinoma, ${ }^{\mathrm{e}}$ human prostate adenocarcinoma, ${ }^{\mathrm{f}}$ human pancreatic carcinoma, ${ }_{\mathrm{g}, \mathrm{h}}$ ovarian cancer cells; ${ }^{\mathrm{I}, \mathrm{j}}$ cervical cancer; ${ }^{\mathrm{k}}$ bladder cancer; ${ }^{1}$ skin cancer, ${ }^{\mathrm{m}}$ human colon adenocarcinoma, ${ }^{\mathrm{n}}$ hepatoma cell-line, ${ }^{\mathrm{o}}$ leukemia cells, ${ }^{\mathrm{p}}$ promyelocytic leukemia cells; ${ }^{\mathrm{q}}$ Ehrlich ascites tumor cells.

resulted in the identification of a series of cytotoxic acetogenins including notably: (2,4-cis and trans-)annomontacinones (i), annonacin (ii), giganenin (iii), gigantecin (iv), 4-deoxygigantecin, (2,4-cis and trans)gigantecinones, 4-acetylgigantetrocin A (v), goniotrionin (vi), gigantransenin $\mathrm{A}$ (vii) and $\mathrm{C}$ (viii), gigantrionenin (ix), gigantetrocin (x), goniotetrocine (xi), (2,4-cis and trans)-gigantetrocinones, gonionenin (xii), (2,4-cis and trans)-gonioneninones (xiii), 4-deoxygigantenin (xiii), 4-deoxyannomontacin (xiv), goniothalamicin (xv), pyranicin (xvi), gigantriocin (xvii), goniotriocin, (2,4-cis and trans)-isoannonacins, longicoricin, longifolicicin, longimicin C, cis-gigantrionenin (xviii), pyragoniocin (xix), xylomaticin, and (2,4-cis and trans)-xylomaticinones (Fig. 1) (19-33). Gigantransenins A, and C showed selective inhibitory effects on the human breast tumor cell-line (MCF-7) comparable with the potency of adriamycin (26). Both goniotetracin, and 2,4-cis- and trans-gonioneninone are selectively and significantly cytotoxic to the human pancreatic tumour cell line (PACA-2) (29). Pyranicin exhibited a selective cytotoxic against the pancreatic cell line (PACA-2) in a panel of six human solid tumor cell lines, with pyranicin showing 10 times the potency of adriamycin (30). 
Jiang et al. isolated donhepocin (xx), goniodin (xxi), donhexocin (xxii) and donbutocin (xxiii), from G. donnaiensis Finet \& Gagnep. collected from Guangxi Province, China (34-36). Gardnerilins A (xxiv) and B (xxv) from G. gardneri Hook.f. \& Thoms collected from DiaoLo mount, Hainan Province, China, gave cytotoxic $\mathrm{IC}_{50}$ values against Bel 7402 human tumor cell lines of 3.6 and $8.5 \mu \mathrm{g} / \mathrm{ml}$, respectively $(37,38)$ (Fig. 1). The mode of action of acetogenins is discussed next.

\section{Mode of Action of Acetogenins: Inhibition of NADH-ubiquinone Oxidoreductase}

Acetogenins have very potent and diverse biological effects owing to the fact that they inhibit enzymatic activity of a key enzyme in Eukaryotic cells: mitochondrial NADH-ubiquinone oxidoreductase (complex I). To date the most potent existing inhibitor of this enzyme is an acetogenin known as bullatacin (39-41). In regards to the precise molecular mode of action of acetogenins against the enzyme, there is an expanding body of evidences to suggest that the most lipophilic moieties are embedded in the mitochondrial membrane allowing suitable position of the pharmacophore. One might set the hypothesis that the tetrahydrofuran (THF) or tetrahydropyran rings as well as the free alkyl substituent fix the molecule, whereas the lactones maintained by an alkyl spacer acts on the active site of the enzyme as illustrated in Fig. $2(42,43)$. The work of Motoyuki et al. (13) lends strong support to that hypothesis. They synthesized series of acetogenins and assessed their activity against bovine heart mitochondrial complex I and showed that the length of the alkyl spacer and the polarity of THF surroundings were very important structural factor and that the $\gamma$-lactone and THF ring moieties act in a cooperative manner on complex I with the support of some specific conformation of the alkyl spacers as illustrated in Fig. 2.

The cytotoxic activity of acetogenin has prompted further work in an effort to discover synthetic acetogenins (44-46). Oberlies et al. (41) studied the cytotoxicity of acetogenins toward cancerous and normal cells and showed that they are selectively cytotoxic against cancerous cells and also effective for drug-resistant cancer cells, while exhibiting only minimal toxicity to 'normal' non-cancerous cells. However, further work is needed to render acetogenins more specific to cancerous cells and very much less active against normal cells or significantly heavy side-effects will preclude clinical trials. A possible approach would perhaps be to use antigenguided or receptor-guided forms of administrations by associating acetogenins to specific carriers, hemisynthesis could be of value in this instance. More specific cytotoxic principles from Goniothalamus species are styryl-lactones reviewed in the next section.

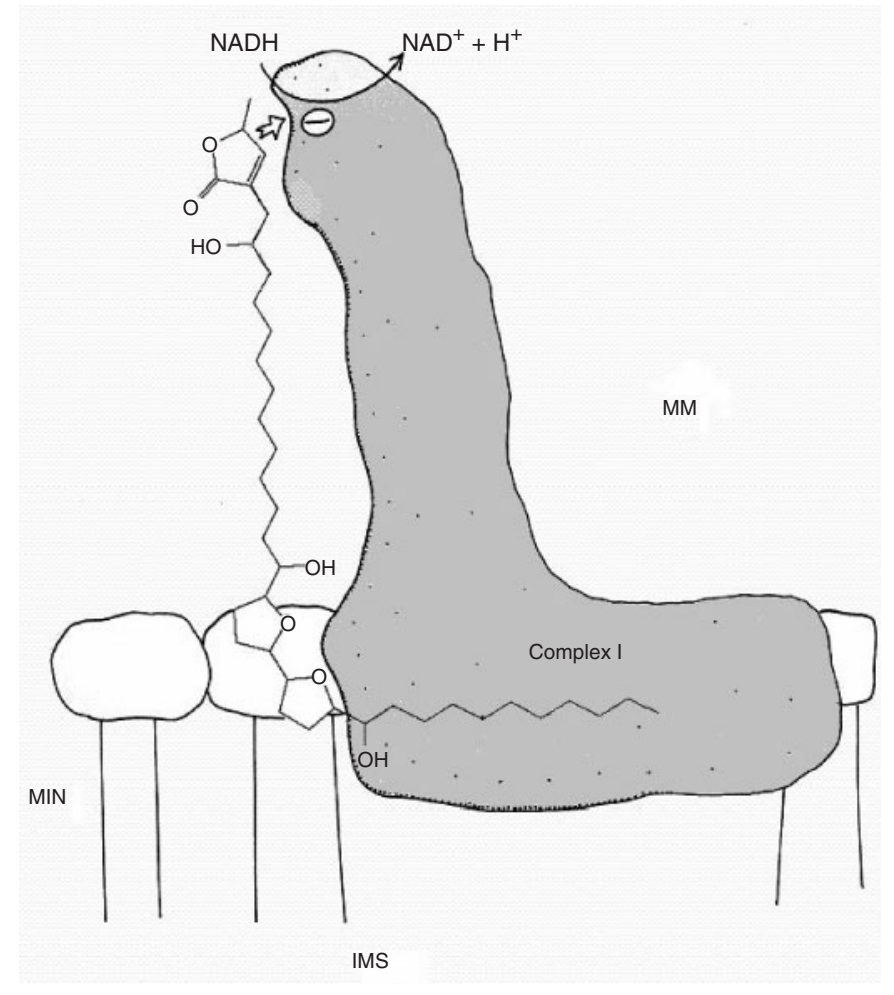

Figure 2. Hypothetical molecular mode of action of bullatacin against Complex I. MM: Mitochondrial Matrix, MIN: Mitochondrial Inner Membrane; IS: Intermembrane Space.

\section{Styryl-lactones: Phenolic Compounds}

Styryl-lactones are low molecular weight phenolic compounds, which, like acetogenins are essentially found in members of the Annonaceae family and present a lactonic pharmacophore (9). Examples of styryllactones from Goniothalamus species are goniothalamin (i), altholactone (ii) and cardiopetalolactone (iii) (Fig. 3).

Jewers et al. (47) first reported goniothalamin as the active constituent of the bark of $G$. andersonii, $G$. macrophyllus Miq. and G. malayanus collected in the peat-swamp of Sarawak. Altholactone was characterized from G. arvensis Scheff. collected in the National Park of Varirata in the Central Province of Papua New Guinea and from the $G$. borneensis Mat-Salleh collected in Malaysia $(48,49)$. Cardiopetalolactone was characterized from the stem bark of G. cardiopetalus Hook.f. \& Thoms. collected from Palaruvi forest in Kerala in India, with altholactone, goniopypyrone, goniothalamin, goniodiol (iv), goniofufurone (v) and goniofupyrone (vi) (50,51). Goniofufurone, goniopypyrone, goniothalamin, goniodiol, goniotriol (vii) and 8-acetylgoniotriol (viii) were isolated from the roots of $G$. griffithii $(52,53)$. An isomer of altholactone, (+)-isoaltholactone (ix), was isolated from stem bark of G. malayanus, and from the leaves of G. montanus J. Sincl. and the roots of G. tapis Miq. (54). Goniolactones A-F were identified from the roots of G. cheliensis (55). Digoniodiol, deoxygoniopypyrone A, 
<smiles>O=C1C=CC[C@H](CCc2ccccc2)O1</smiles>

(i)

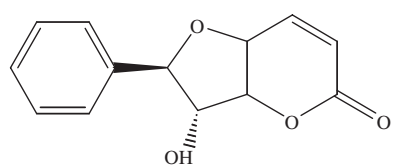

(ii)

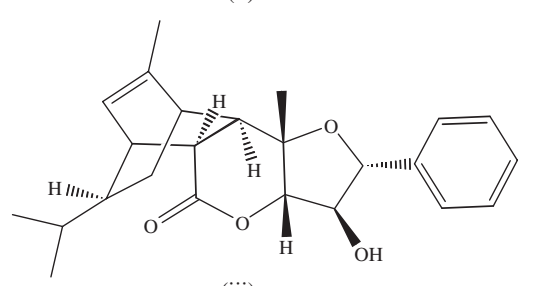

(iii)

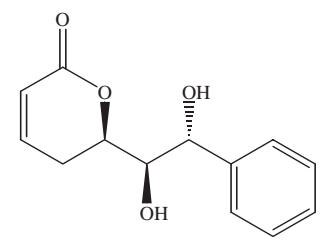

(iv)

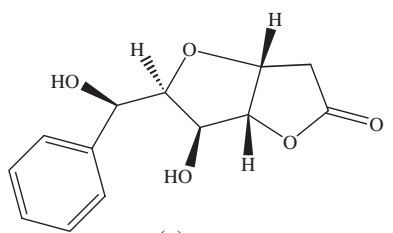

(v)

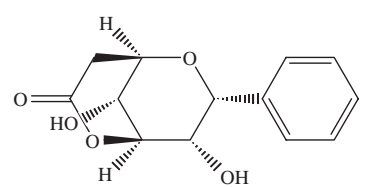

(vii)

Figure 3. Styryl-lactones from Goniothalamus species

goniofupyrone, goniothalamin, deoxygoniopypyrone A, gonodiol-8-monoacetate and gonotriol $(\mathrm{x})$ and were characterized from the aerial parts of G. amuyon collected in the southern part of Taiwan near the coastal regions (56-59). The petroleum ether extract of the stem bark of $G$. sesquipedalis collected in Bangladesh yielded 5-isogoniothalamin oxide (60). 5-Acetyl goniothalamin (xii) was characterized from G. uvaroides King collected in Bangladesh (61). Chen et al. (62) isolated howiinol A from G. howii Merr. (xii). The mode of cytotoxic action of styryl-lactone is described subsequently.

\section{Mode of Cytotoxic Action of Styryl-lactones: Apoptosis}

The evidence currently available clearly indicate that goniothalamin and congeners are toxic for several sorts<smiles>O=C1C=C[C@@H](O)[C@H]([C@H](O)c2ccccc2)O1</smiles><smiles>C[C@H](O)[C@H](O)[C@H]1OC(=O)C=C[C@H]1O</smiles>

(ix)<smiles>O=C1C=CC2O[C@@H](c3ccccc3)[C@H](O)[C@H]2O1</smiles>

(x)

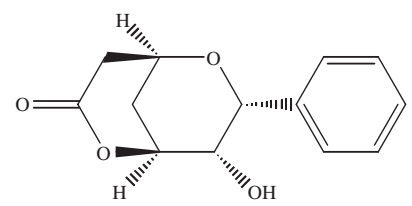

(xi)

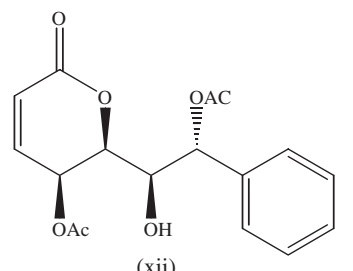<smiles>O=C1C=C[C@@H](O)[C@H]([C@H](O)[C@H](OC(=O)/C=C/c2ccccc2)c2ccccc2)O1</smiles>

(xiii)

of cancer cells cultured in vitro including HL-60 leukemia cells, breast cancer cell line MCF-7, liver cancer cell line HepG2, PANC-1, HeLa cell lines (63-80) (Table 1). Current paradigms of apoptosis suggest that styryllactones from Goniothalamus activate in mammalian cells the caspases enzymatic cascades via a loss of mitochondrial transmembrane which results in the release of mitochondrial cytochrome $c$ (72). To date, the very precise premitochondrial mechanism involved in this activation remains an enigma, and an exciting fact is that the activation of caspases, 3, 6, 7 and 9 is a sign of TRAIL receptors/Bax activation (65). Other examples of goniothalameous styryl-lactones of possible chemotherapeutic value are altholactone, goniolactone $\mathrm{B}$ and howiinol. Altholactone is apoptogenic in HL-60 
promyelocytic leukemia cells via oxidative stress and mitochondrial respiratory abrogation (75,76). Goniolactone B exhibited significant cytotoxicity against A2780, HCT-8 and $\mathrm{KB}$ cells with $\mathrm{IC}_{50}$ values of 7.40, 4.43 and $7.23 \mu \mathrm{M}$, respectively (55). Howiinol A showed significant antitumor activities toward human tumor cell in vitro and in vivo (77-81). A remarkable advance in the pharmacological knowledge of howiinol $\mathrm{A}$ has been provided by the work of $\mathrm{He}$ et al. Using techniques of cell growth curve determination, MTT test, soft agar colony assay and experimental therapy of transplantable tumors in mice, they showed that howiinol exerts potent inhibitory effect on cancer cells including drug-resistant cell line, KB/VCR 2000, whereas normal cells are less affected. Howiinol is active in rodents infected with $\mathrm{H} 22$ hepatoma and Lewis lung cancer and ascetic sarcoma 180. In addition to flow cytometry technique, they showed that the cycle of howiinol A block is used to analyze the cell cycle of L1210 cells from G1 phase to S phase with structural damage on DNA molecules. Tian et al. (82) showed that Goniothalamus styryl-lactones which are cytotoxic against both HepG2 and HepG2-R cell lines show less toxicity on normal mice hepatocytes as the $\mathrm{IC}_{50}$ values of them on normal mouse hepatocytes were about 3 times of that on HepG2. They demonstrated that cells treated with goniothalamin and altholactone stopped to multiply at $\mathrm{G}(2) / \mathrm{M}$ and were apoptotic, whereas cells with chromosomes gathered at the equator were easily found in gonodiol-treated cultures.

Indicating that not all Goniothalamus styryl-lactones are exclusively apoptogenic, Zhong et al. (83) investigated the apoptosis-inducing effect of styryl-lactones from $G$. cheliensis, on human promyelocytic leukemia HL-60 and showed the activation of caspase-3, reduced the expression of the anti-apoptotic gene $\mathrm{Bcl}-2$, and increased the expression of the pro-apoptotic gene Box via cAMPdependent protein kinase mechanism. Taking into consideration the available evidence, one might propose the hypothesis that goniothalamin and congeners induce apoptosis at the TRAIL-BAX system level via protein kinase modulation. Protein kinase has long been known to be involved in cell growth and proliferation. Wang et al. showed that protein kinase is involved in apoptosis mediated by TRAIL (tumor necrosis factorrelated apoptosis-inducing ligand) (84). An example of styryl-lactone which inhibits kinase is flavokavain A from kava, or Piper methysticum in the closely related family Piperaceae (85). The Fig. 4 shows the similitude of chemical structure between flavokavain and goniothalamin.

A possible mechanism of action for Goniothalamus styryl-lactones would be a cAMP-dependent protein kinase-mediated TRAIL-induced apoptosis, by stimulating TRAIL-induced translocation of Bax from cytosol to mitochondria, loss of mitochondrial transmembrane

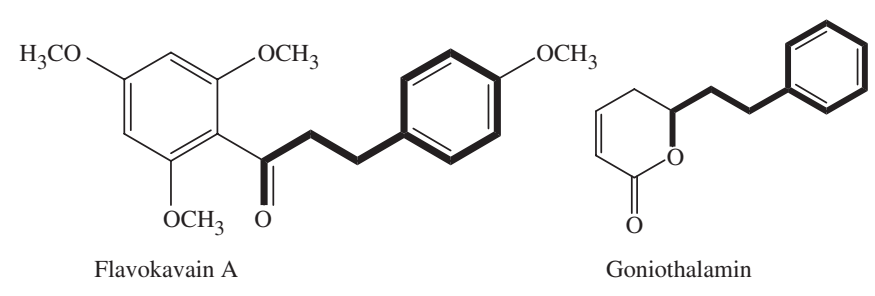

Figure 4. Note the proximity of chemical structure between flavokavain $\mathrm{A}$, an inhibitor of protein kinase, and goniothalamin. What is the precise activity of styryl lactones against protein kinases?

potential, and subsequent release of cytochrome $c$ from mitochondria and activation of caspases, SMAC/Diablo, endo $G$ and finally chromatin deterioration (Fig. 5). Protein kinase modulators are of immense therapeutic usefulness. Note that flavokavains are present in the genus Goniothalamus, as discussed next.

\section{Other Phytochemicals}

The aerial parts of $G$. gardneri have yielded the known flavonoids $2^{\prime}$-hydroxy-4,4',6'-trimethoxychalcone (flavokavain A), 2',4'-dihydroxy-4,6'-dimethoxydihydrochalcone, 4,2',4'-trihydroxy-6'-methoxydihydrochalcone, 5,7,4'-trimethoxyflavanone (naringenin trimethyl ether) and 7-hydroxy-5,4'-dimethoxyflavanone (tsugafolin) together with three novel compounds, the dimer characterized as (rel)-1 $\beta, 2 \alpha$-di-(2,4-dihydroxy-6methoxybenzoyl)-3 $\beta, 4 \alpha$-di-(4-methoxyphenyl)-cyclobutane, $2^{\prime}, 4^{\prime}$-dihydroxy-4,6'-dimethoxychalcone and 2'-hydroxy4,4',6'-trimethoxydihydrochalcone (86). A similar study of the aerial parts of $G$. thwaitesii led only to the isolation of the known flavonoids myricetin 4'-O-methyl ether-3$O-\alpha$-L-rhamnopyranoside (mearnsitrin) and myricetin-3$O$-methyl ether (annulatin), together with a series of triterpenes friedelinol, friedelin and betulinic acid (86).

Isoquinoline alkaloids were characterized from $G$. атиyon (87). Other miscellaneous secondary metabolites isolated from members of this genus include goniopedaline, a phenanthrene lactam, aristololactam A-II and its $N, O$-diacetyl derivative, taliscanine, aurantiamide acetate and $\beta$-sitosterol and its $\beta$-D-glucoside were isolated from the leaves and twigs of G. sesquipedalis Hook.f. \& Thoms. (88). 3-Amino naphthoquinones were characterized from the stem bark of G. marcanii (89). Alkaloids were characterized from G. griffithii and essential oils were distilled from $G$. malayanus, $G$. uvarioides, G. macrophyllus and G. andersonii $(90,91)$. In the genus Goniothalamus, 138 species still await to be phytochemically investigated, including G. scortechinii, the antibacterial property of which is reported in the next section. 


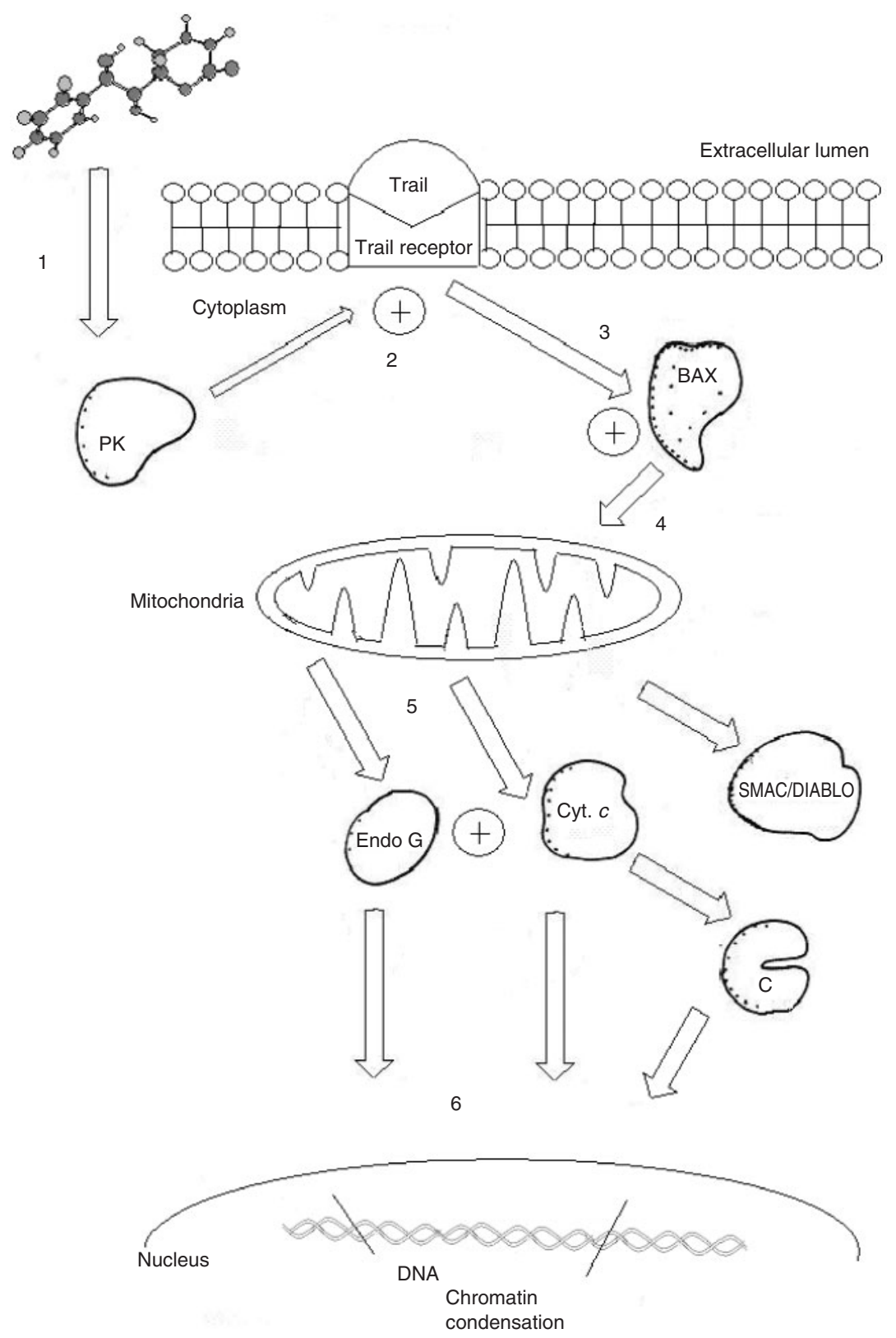

Figure 5. Putative mechanism of action of Goniothalamus styryl-lactones in apoptosis. TRAIL R: TRAIL receptor, Cyt. $c$ : Cytochrome $c$; C: caspases. 1: styryl-lactone interacts with cellular kinase, 2: kinase mediation of TRAIL induction of apoptosis, 3: TRAIL induced translocation of Bax to mitochondria, 4, 5: release of cytochrome $\mathrm{C}$ and activation of caspases, SMAC/Diablo, EndoG, 6: chromatin condensation and cellular death.

\section{Antibacterial Activity of G. Scortechinii}

G. scortechinii or in Malay akar gajah beranak (climber of the elephant bringing forth) is a small tree found from Penang to Selangor and Pahang used by Malays apparently freely, either alone or with other substances after childbirth, and taken internally to prevent bacterial infection (3). The plant is known to exhibit potent schizonticidal activity in vitro (92). We report the first evaluation of the antibacterial activity of hexane, dichloromethane and aqueous fractions of G. scortechinii. The plant was collected from $6^{\circ}$ North and $98^{\circ}$ East, near
Kuala Kangsar, State of Perak, Malaysia in August 2004, $300 \mathrm{~m}$ above sea level. The plant material was identified on comparison with specimens available at the Herbarium of the 'Forest Research Institute of Malaysia', Kepong, Malaysia. A voucher specimen (number W1332) has been deposited in our Herbarium collection for future reference. Finely powdered, air-dried leaves of G. scortechinii $(800 \mathrm{~g})$ were extracted with methanol (21) using a soxhlet apparatus. Hexane $(250 \mathrm{ml})$, dichloromethane $(250 \mathrm{ml})$, and water fractions $(250 \mathrm{ml})$ were obtained by the partitioning of liquid methanol extract $(250 \mathrm{ml})$ (yield: $5.52,8.43,64.5)$. 
The different fractions obtained were concentrated with a rotary evaporator and brought to complete dryness over water bath to yield the crude extracts. Hexane fraction (yield: 5.52) gave a positive chemical test for steroids, dichloromethane fraction (yield: 8.43) gave a positive chemical test for steroids and terpenes, and aqueous fraction (yield: 64.5) gave a positive chemical test for tannins (93). These extracts were screened for antibacterial activity using the following antibacterial assay.

The crude methanol extract of $G$. scortechinii and fractions were subjected to antimicrobial assay using the disc diffusion method of Bauer et al. (94). Both Grampositive and Gram-negative bacteria (Table 2) were obtained from the stock cultures of the Department of Medical Microbiology at the University of Malaya. The organisms were of the American Typed Culture Collections (ATCC) and some nosocomial isolates. The organisms included Bacillus sp., Staphylococcus aureus ATCC 25923, Staphylococcus aureus ATCC 29213, Enterococcus faecalis ATCC 24922, Pseudomonas aeruginosa ATCC 27853, Escherichia coli ATCC 25922, Klebsiella pneumoniae, Shigella sonnei, Shigella flexneri and a yeast Candida albicans (ATCC 90028). The organisms selected for testing in this experiment are commonly responsible for foodborn and nosocomial bacterial infections (95). Mueller-Hinton agar was prepared according to the manufacturer's instruction. It was dispensed into sterile plates in $20 \mathrm{ml}$ aliquots. After gelling and drying, the plates were seeded with appropriate organisms by streaking evenly in three planes onto the surface of the medium with cotton swabs.

Table 2. Antibacterial activity of extractives from G. scortechinii

\begin{tabular}{lllllll}
\hline & H & D & A & M & S & N \\
\hline Gram-positive bacteria & & & & & & \\
Bacillus sp. & 13 & 20 & - & 20 & 18 & \\
Staphylococcus aureus ATCC 25923 & 14 & 27 & - & 21 & 16 & \\
Staphylococcus aureus ATCC 29213 & 14 & 23 & - & 20 & 16 & \\
Enterococcus faecalis ATCC 24922 & - & 20 & - & 14 & 14 & \\
Streptococcus pneumoniae ATCC 49619 & - & 21 & - & 13 & 10 \\
Gram-negative bacteria & & & & & & \\
Pseudomonas aeruginosa ATCC 27853 & - & - & - & - & 17 & \\
Escherichia coli ATCC 25922 & - & 19 & 10 & 13 & 20 & \\
Klebsiella pneumoniae & - & 11 & - & - & 20 & \\
Shigella sonnei & 16 & 28 & - & 18 & 20 & \\
Shigella flexneri & - & 13 & 7 & - & 13 & \\
Proteus sp. & - & 17 & 12 & 10 & 20 & \\
Yeast & & & & & & \\
Candida albicans ATCC 90028 & 13 & 23 & - & 9 & & 17 \\
\hline
\end{tabular}

Average zone of inhibition (in $\mathrm{mm}$ ) of triplicate including the diameter of the filter paper disc $(6 \mathrm{~mm}) . \mathrm{H}=$ hexane fraction $(5 \mathrm{mg} / \mathrm{disc})$ $\mathrm{D}=$ dichloromethane fraction $(5 \mathrm{mg} /$ disc $) \quad \mathrm{A}=$ aqueous fraction (5 $\mathrm{mg} /$ disc) $\quad \mathrm{M}=$ methanol fraction $\quad(5 \mathrm{mg} /$ disc $) \quad \mathrm{S}=$ streptomycin $(10 \mu \mathrm{g} /$ disc $) \mathrm{N}=$ Nystatin $(100 \mathrm{IU})$.
The inoculum was dried for $5 \mathrm{~min}$. Sterile filter paper disks $(6 \mathrm{~mm}$ diameter) soaked with $50 \mu \mathrm{l}$ of extract $(100 \mathrm{mg} / \mathrm{ml})$ were placed onto the agar with flamed forceps and gently pressed down to ensure contact. Streptomycin $(10 \mu \mathrm{g} / \mathrm{disc})$ and nystatin (100 IU) were used as a positive standard against bacteria and fungi as they are both inexpensive and broad spectrum antimicrobials. The plates were incubated at $37^{\circ} \mathrm{C}$ for $24 \mathrm{~h}$. The zones of inhibition were measured with a ruler. The experiment was carried out in triplicate. Results obtained for antibacterial activity of the crude methanol extract of G. scortechinii and fractions are reported in Table 2 . Methanol, hexane, dichloromethane and water used for reconstitution of the extracts showed no activity. Analysis of the data revealed that among the tested fractions, the dichloromethane fraction exhibited the highest rates of antibacterial activity. It showed antibacterial activity against $S$. aureus ATCC 25923: $23 \mathrm{~mm}, S$. aureus ATCC 29213: $27 \mathrm{~mm}, \quad$ E. faecalis ATCC 24922: $20 \mathrm{~mm}$, Escherichia coli ATCC 25922: $19 \mathrm{~mm}$, Bacillus sp.: $20 \mathrm{~mm}, \quad$ K. pneumoniae: $13 \mathrm{~mm}$ (Fig. 6), S. sonnei: $28 \mathrm{~mm}$, S. flexneri: $13 \mathrm{~mm}$, and Proteus sp. $17 \mathrm{~mm}$. The extract inhibited the growth of C. albicans ATCC 90028. It was inactive against $P$. aeruginosa ATCC 27853.

This report is the first data available on the antibacterial activity of Goniothalamus species and lends support the traditional use of Goniothalamus species as postpartum remedy. An interesting development from these results would be first to identify the active constituents and next to study their precise molecular activity against bacteria. Note that mitochondria in eukaryotic cells take their origin in pro-bacterial ancestors from which they inherited NADH:ubiquinone oxidoreductase (96). One can perhaps envisage a new antibacterial pathway that would encompass a 'bacterial apoptosis'. One wonders.

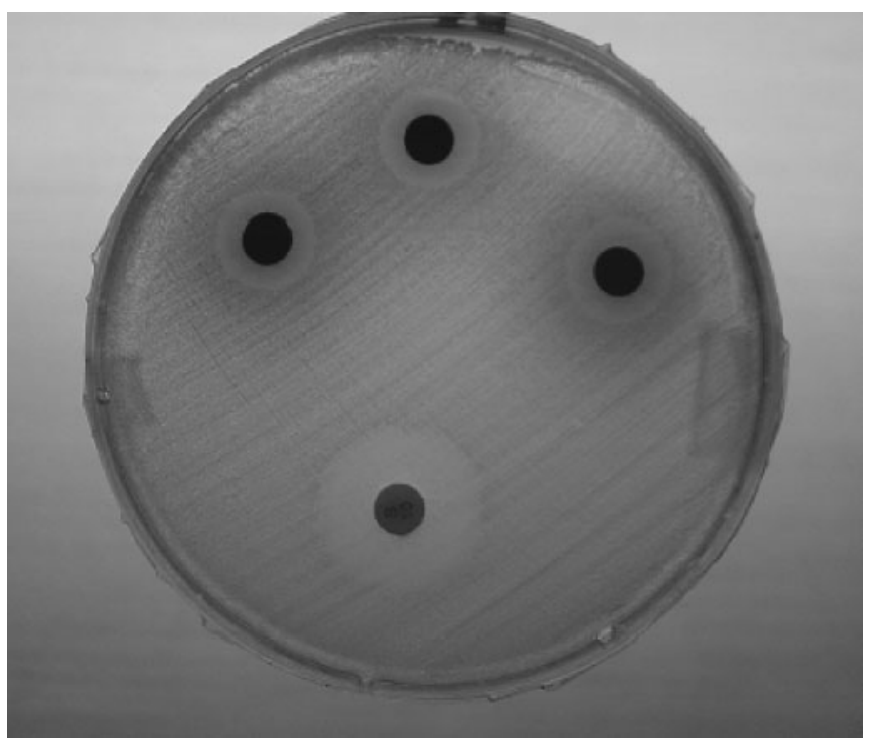

Figure 6. Antibacterial activity of G. scortechinii against Klebsiella pneumoniae. 


\section{Conclusion}

G. scortechinii was investigated as part of our study on the medicinal plants of Asia-Pacific $(9,10,97-100)$ A critical factor for Goniothalamus' use as a medicinal herb is its content of styryl-lactones, which promote apoptosis in mammalian cells. One might propose the hypothesis that the abortifacient and/or post-natal and anti-inflammatory reported traditional uses of Goniothalamus species might involve styryl-lactones since apoptosis is known to play a crucial role in trophoblasts of patients with recurrent spontaneous abortion of unidentified cause, and in $\mathrm{T}$ cells in the human decidua as defense mechanism against rejection of fetal allograft by the maternal immune system $(101,102)$. In addition, goniothalamin induces apoptosis in vascular smooth muscle cells, the growth of which is required to allow embryo implantation and the development of the blood supply for fetal survival and inhibit the cell surface expression of intercellular adhesion molecule 1 and vascular cell adhesion molecule 1 on the surface of murine endothelial cells $(103,104)$

In regards to the result obtained for antibacterial activity of the crude methanol extract of $G$. scortechinii and fractions, it can be concluded that the dichloromethane extract of $G$. scortechinii is very active against both Gram-positive and Gram-negative bacteria. and the results obtained tend to answer positively the question of Chinnok et al. (105). This work illustrates the fact that the careful study of the biochemical architecture of medicinal plants represents a fascinating and fruitful aspect of pharmaceutical research (106). In regards G. scortechinii, it will be interesting to know whether further studies on this plant disclose any molecules the treatment of nosocomial urinary, respiratory and wound nosocomial infections ( $S$. aureus, E. coli and $K$. pneumoniae) which are developed by hospital patients.

In summary the evidence for the existence of anticancer, antibacterial and antiviral agents in the genus Goniothalamus is strong and it seems likely that further consistent and systematic research on this genus of flowering plants will lead to the discovery of antineoplastic and antimicrobial agents. If enough botanical, phytochemical and pharmacological work is dedicated to this discrete tropical genus of flowering plants, a couple of drugs for the treatment of tumors and/or bacterial and even viral infections should be developed in the relatively close future.

\section{Acknowledgements}

The staffs of the Forest Institute of Malaysia are gratefully acknowledged.

\section{References}

1. Sinclair J. A revision of the Malayan Annonaceae. The garden's Bulletin Singapore 1955;2:149-516.
2. Watt G. Dictionary of the Economic Products of India, Vol. III. London: Allen, 1890, 533.

3. Burkill IH. A Dictionary of the Economic Products of the Malay Peninsula, Vol. 1. London: Crown Agent, 1953, 1097.

4. Quisumbing E. Medicinal Plants of the Philippines. Manila: Bureau of Printing, 1951, 324.

5. Cronquist A. An Integrated System of Classification of Flowering Plants. New York: Columbia University Press, 1981.

6. Saunders RMK. A synopsis of Goniothalamus species(Annonaceae) in Peninsular Malaysia, with a description of a new species. Bot J Linn Soc 2003;142:321-39.

7. Takhtajan A. Diversity and Classification of Flowering Plants. New York: Columbia University Press, 1997.

8. Koek-Noorman J, Westra LY Th., Maas PJM. Studies in Annonaceae. XIII. The role of morphological characters in subsequent classifications of Annonaceae: a comparative survey. Taxon 1990;39:16-32.

9. Wiart C. Medicinal Plants of Asia-Pacific: Drugs for the Future? Singapore: World Scientific Publishing, 2006.

10. Wiart C. Ethnopharmacology of Medicinal Plants: Asia and the Pacific. USA: Humana Press, 2007.

11. Greshoff M. Beschriving der giftige en bedwelmende planten bij de vischvangt in gebruik. 1900;II. Ibid. 29: 1-253.

12. Heyne K. De Nuttige Planten van Indonesie $3^{\text {rd }}$ ed. 1950; Part I: 1-1450; Lui TS. List of Economic Plants in Taiwan Taipei, Taiwan: 92, 1952.

13. Motoyuki T, Kaoru K, Hironori N, Akira T, Hajime I, Hideto M. Definition of crucial structural factors of acetogenins, potent inhibitors of mitochondrial complex I. Biochim Biophys Acta 2000;1460:302-10.

14. Yang S, Yu J, Xu L. Chemical constituents of Annonaceae plants and their antitumour activities. Zhongguо Yi Хие Ке ХиеYиап Хие Bao 2000;22:376-82.

15. Nakanishi Y, Chang FR, Liaw CC, Wu YC, Bastow KF, Lee KH. Acetogenins as selective inhibitors of the human ovarian 1A9 tumor cell line. J Med Chem 2003;46:3185-8.

16. Huang GR, Jiang $\mathrm{S}$, Wu YL, Jin Y, Yao ZJ, Wu JR. Induction of cell death of gastric cancer cells by a modified compound of the annonaceous acetogenin family. Chem Biochem 2003;4: 1216-21.

17. Fu LW, He LR, Liang YJ, Chen LM, Xiong HY, Yang XP, et al. Experimental chemotherapy against xenografts derived from multidrug resistant $\mathrm{KBv} 200$ cells and parental drug-sensitive $\mathrm{KB}$ cells in nude mice by annonaceous acetogenin 89-2. Yaо Хие Хие Bao 2003;38:565-70.

18. Zhu XF, Xie BF, Li ZM, Feng GK, Zeng YX, Liu ZC. Mechanism of apoptosis induced by squamocin in leukemia cells. Yао Хие Хие Bao 2001;36:498-501.

19. Alkofahi A, Rupprecht J, Smith DL, Chang CJ, Mclaughlin JL. Goniothalamin and annonacin: bioactive acetogenins from Goniothamalus giganteus (Annonaceae). Experientia 1988;44:83-5.

20. Alkofahi A, Ma WW, McKenzie AT, Byrn SR, McLaughlin JL. Goniotriol from G. giganteus. J Nat Prod 1989;52:1371-3.

21. Alkofahi A, Rupprecht J, Liu YM, Chang CJ, Smith DL, Mclaughlin JL. Gigantecin: a novel antimitotic and cytotoxic acetogenin, with non adjacent tetrahydrofurane rings, from G. giganteus (Annonaceae). Experientia 1990;46:539-41.

22. Fang XP, Anderson JE, Smith DL, Mc Laughlin JL, Wood KV. Gigantetronenin and gigantrionenin: novel cytotoxic acetogenins from G. giganteus. J Nat Prod 1992;55:1655-63.

23. Xin-ping F, Rong S, Zhe-ming G, Rieser MJ, Miesbauer LR, Smith DL, et al. A new type of cytotoxic annonaceous acetogenin: giganin from G. giganteus.. Bioorg Med Chem Lett 1993:3:1153-6.

24. Gu ZM, Fang XP, Zeng L, Song R, Ng JH, Wood KV, et al. Gonionenin: a new cytotoxic annonaceous acetogenin from G. giganteus and the conversion of mono-THF acetogenins to bis -THF acetogenins. J Org Chem 1994;59:3472-9.

25. Zeng L, Zhang Y, Ye Q, Shi G, He K, McLaughlin JL. Cis-gigantrionenin and 4-acetyl gigantetrocin $\mathrm{A}$, two new bioactive annonaceous acetogenins from $G$. giganteus, and the stereochemistries of acetogenin 1,2,5-triols. Bioorg Med Chem 1996;4:1271-9. 
26. Zeng L, Yan Z, McLaughlin JL. Gigantransenins A, B, and C, novel mono-THF acetogenins bearing trans double bonds, from G. giganteus (Annonaceae). Tetrahedr Lett 1996;37:5449-52.

27. Feras QA, Zeng L, Zhang Y, Ye Q, Hopp DC, Schwedler JT, et al. 4-deoxyannomontacin and (2,4-cis and trans)-annomontacinone, new bioactive mono-tetrahydrofuran annonaceous acetogenins from G. giganteus. Bioorg Med Chem 1997;5:549-55.

28. Feras QA, Zhang Y, Rogers L, McLaughlin JL. (2,4-cis and trans)gigantecinone and 4-deoxygigantecin, bioactive nonadjacent bis- tetrahydrofuran annonaceous acetogenins, from $G$ giganteus. J Nat Prod 1997;60:929-33.

29. Feras QA, Yan Z, Jingling R, McLaughlin JL. Mono-tetrahydrofuran acetogenins from G. giganteus. Phytochemistry 1998;49:761-8.

30. Feras QA, Lingling R, Yan Z, McLaughlin JL. Unusual bioactive annonaceous acetogenins from G. giganteus. Tetrahedron 1998;54:5833-44.

31. Feras QA, Rogers L, Zhang Y, McLaughlin JL. Goniotriocin and (2,4-cis- and -trans)-xylomaticinones, bioactive annonaceous acetogenins from G. giganteus. J Nat Prod 1999;62:31-4.

32. Zeng L, Zhang Y, Qing Y, Gouen S, Kan H, McLaughlin JL. cis-Gigantrionenin and 4-acetyl gigantetrocin A, two new bioactive annonaceous acetogenins from $G$. giganteus, and the stereochemistries of acetogenin 1,2,5-triols. Bioorg Med Chem 1996;4:1271-9.

33. Feras QA. Novel anti-cancer and pesticidal components from G. giganteus (Annonaceae). Dissertation, Purdue Libraries, 1998.

34. Jiang Z, Chen Y, Ruo-Yun Ch, De-Quan Y. Mono-tetrahydrofuran ring acetogenins from G. donnaiensis. Phytochemistry 1997; 46:327-31.

35. Jiang Z, Chen Y, Chen RY, Yu DQ. Linear acetogenins from G. donnaiensis. Phytochemistry 1998;49:769-75.

36. Jiang Z, Chen RY, Chen Y, Yu DQ. Donnaienin, a new acetogenin bearing a hydroxylated tetrahydrofuran ring. $J$ Nat Prod 1998;61:86-8.

37. Chen Y, Jiang Z, Chen RR, Yu DQ. Two linear acetogenins from G. gardneri. Phytochemistry 1998;49:1317-21.

38. Seidel V, Bailleul F, Waterman PG. A linear acetogenin from G. gardneri. Phytochemistry 1999;52:1101-3.

39. Morre DJ, de Cabo R, Farley C, Oberlies NH, McLaughlin JL. Mode of action of bullatacin, a potent antitumor acetogenin: inhibition of NADH oxidase activity of HeLa and HL-60, but not liver, plasma membranes. Life Sci 1995;56:343-8.

40. Feras AQ, Kaakeh W, Bennett GW, McLaughlin JL. Annonaceous acetogenins as natural pesticides: potent toxicity against insecticidesusceptible and -resistant German cockroaches (Dictyoptera: Blattellidae). J Econ Entomol 1998;J91:641-9.

41. Oberlies NH, Croy VL, Harrison ML, McLaughlin JL. The Annonaceous acetogenin bullatacin is cytotoxic against multidrugresistant human mammary adenocarcinoma cells. Cancer Lett 1997;115:73-9.

42. Shimada H, Kozlowski JF, Mclaughlin JL. The localizations in liposomal membranes of the tetrahydrofuran ring moieties of the annonaceous acetogenins, annonacin and sylvaticin, as determined by 1H NMR spectroscopy. Pharmacol Res 1998;37:357-64.

43. Zeng BB, Wu Y, Jiang S, Yu Q, Yao ZJ, Liu ZH, et al. Studies on mimicry of naturally occurring annonaceous acetogenins: non-THF analogues leading to remarkable selective cytotoxicity against human tumor cells. Chemistry 2003;9:282-90.

44. Kojima N. Systematic synthesis of antitumor annonaceous acetogenins. Yakugaku Zasshi 2004;124:673-81.

45. Rodier S, Le Huerou Y, Renoux B, Doyon J, Renard P, Pierre A, et al. New cytotoxic analogues of annonaceous acetogenins. Anticancer Drug Des 2001;16:109-17.

46. Jiang S, Liu ZH, Sheng G, Zeng BB, Cheng XG, Wu YL, et al. Mimicry of annonaceous acetogenins: enantioselective synthesis of a (4R)-hydroxy analogue having potent antitumor activity. $J$ Org Chem 2002;17;67:3404-8.

47. Jewers K, Davis JB, Dougan J, Manchanda AH, Blunden G, Aye K, et al. Goniothalamin and its distribution in four Goniothalamus species. Phytochemistry 1972;11:2025-30.

48. Bermejo A, Blazquez MA, Rao KS, Cortes D. Styryl-lactones from G. arvensis. Phytochemistry 1998;47:1375-80.

49. Shu-Geng C, Xiao-Hua W, Keng-Yeow S, Tan BHK, Pereira JT, Swee-Hock G. Styryl-lactone derivatives and alkaloids from G. borneensis (Annonaceae). Tetrahedron 1998;54:2143-8.
50. Hisham A, Harassi A, Shuaily W, Shizue E, Fujimoto Y. Cardiopetalolactone: a novel styryl-lactone from G. cardiopetalus. Tetrahedron 2000;56:9985-89.

51. Hisham A, Toubi M, Shuaily W, Ajitha MDB, Fujimoto Y. Cardiobutanolide, a styryl-lactone from G. cardiopetalus. Phytochemistry 2003;62:597-600.

52. Mu Q, Tang WD, Liu RY, Li CM, Lou LG, Sun HD, et al. Constituents from the stems of $G$. griffithii. Planta Med 2003;69:826-30.

53. Zhang YJ, Zhou GX, Chen RY, Yu DQ. Styryl-lactones from the rhizomes of G. griffithii. J Asian Nat Prod Res 1999;1:189-97.

54. Steven MC, Laily BD, Abdul L, Kamarudin MS, Mohd WS, Brian WS, et al. (+)Isoaltholactone: a furanopyrone isolated from G. species. Phytochemistry 1990;29:1701-4.

55. Wang S, Zhang YJ, Chen RY, Yu DQ. Goniolactones A-F, six new styrylpyrone derivatives from the roots of G. cheliensis. J Nat Prod 2002;65:835-41.

56. Lan YH, Chang FR, Liaw CC, Wu CC, Chiang MY, Wu YC. Digoniodiol, deoxygoniopypyrone A, and goniofupyrone A: three new styryl-lactones from G. amuyon. J Nat Prod 2002;40:835-41.

57. Lan YH, Chang FR, Yu JH, Yang YL, Chang YL, Lee SJ, et al. Cytotoxic styrylpyrones from $G$. amuyon. $J$ Nat Prod 2003; 66:487-90.

58. Wu YC, Duh CY, Chang FR, Chang GY, Wang SK, Chang JJ, et al. The crystal structure and cytotoxicity of goniodiol-7monoacetate from G. amuyon. J Nat Prod 1991;54:1077-81.

59. Yang-Chang W, Fang-Rong C, Chang-Yih D, Shang-Kwei W, Tian-Shung W. Cytotoxic styrylpyrones of $G$. amuyon. Phytochemistry 1992;31:2851-3.

60. Hasan CM, Mia MY, Rashid MA, Connolly JD. 5-Acetoxyisogoniothalamin oxide, an epoxystyryl lactone from G. sesquipedalis. Phytochemistry 1994;37:1763-4.

61. Fasihuddin BA, Wan AT, Siraj O, Atan MS. 5-Acetyl goniothalamin, a styryl dihydropyrone from G. uvaroides. Phytochemistry 1991;30:2430-1.

62. Chen R, Yu D, Ma L, Wu F, Song W. The chemical constituents of G. howii Merr. Yao Xиe Xие Baо 1998;33:453-6.

63. Inayat-Hussain SH, Osman AB, Din LB, Ali AM, Snowden RT, MacFarlane $M$, et al. Caspases-3 and -7 are activated in goniothalamin-induced apoptosis in human Jurkat T-cells. FEBS Lett 1999;456:379-383.

64. Teck A, Chien L, Lope H, Tan AN. Styrylpyrone Derivative (SPD) induces apoptosis in a caspase-7-dependent manner in the human breast cancer cell line MCF-7. Cancer Cell Int 2003;3:16-22.

65. Chien AL, Pihie AH. Styrylpyrone derivative induces apoptosis through the up-regulation of Bax in the human breast cancer cell line MCF-7. J Biochem Mol Biol 2003;36:269-74.

66. de Fatima A, Kohn LK, Antonio MA, de Carvalho JE, Pilli RA. (R)-Goniothalamin: total syntheses and cytotoxic activity against cancer cell lines. Bioorg Med Chem 2005;13:2927-33.

67. Pihie AHL, Stanslas J, Din LB. Non-steroid receptor-mediated antiproliferative activity of styrylpyrone derivative in human breast cancer cell lines. Anticancer Res 1998;18:1739-43.

68. Hawariah A, Stanslas J. Antagonistic effects of styrylpyrone derivative (SPD) on 7,12-dimethylbenzanthracene-induced rat mammary tumors. In Vivo 1998;12:403-10.

69. El-Sharkawi S, Yusuf Z, Pihie AHL, Ali AM. Metabolism of goniothalamin in animal and microbial systems. Bull Chim Farmaceutica 1996;135:35-40.

70. Ali AM, MacKeen MM, Hamidi M, Aun QB, Zauyah Y, Azimahtol HLP, et al. Cytotoxicity and electron death cell induced by goniothalamin. Planta Med 1997;63:81-3.

71. Ali AM, Umar-Tsafe N, Mohamed SM, Inayat-Hussein SH, Oo KT, Yusoff $\mathrm{K}$, et al. Apoptosis induction in CEM-SS T-lymphoblastic leukemic cell line by goniothalamin. $J$ Biochem Mol Biol Biophys 2001;5:253-61.

72. Inayat-Hussain SH, Annuar BO, Din LB, Ali AM, Ross D. Loss of mitochondrial transmembrane potential and caspase-9 activation during apoptosis induced by the novel styryl-lactone goniothalamin in HL-60 leukemia cells. Toxicology in Vitro 2003; 17:433-9.

73. Umar-Tsafe N, Mohamed-Said MS, Rosli R, Din BD, Lai LC. Genotoxicity of goniothalamin in $\mathrm{CHO}$ cell line. Mutat Res 562:91-102. 
74. Mereyala HB, Joe M. Cytotoxic activity of styryl lactones and their derivatives. Curr Med Chem Anti-Canc Agents 2001; $1: 293-300$.

75. Peris E, Estornell E, Cabedo N, Cortes D, Bermejo A. 3-Acetylaltholactone and related styryl-lactones, mitochondrial respiratory chain inhibitors. Phytochemistry 2000;54:311-5.

76. Inayat-Hussain $\mathrm{SH}$, Osman AB, Din LB, Taniguchi $\mathrm{N}$. Altholactone, a novel styryl-lactone induces apoptosis via oxidative stress in human HL-60 leukemia cells. Toxicol Lett 2002;131:153-9.

77. He J, Ye Y, Xu C. Antitumor activity of howiinol (GHM-10) on L1210 cells in vitro. Yао Хие Хие Вао 1998;33:566-70.

78. He J, Ye Y, Xu C. Studies on the anticancer effect of howiinol A, a new compound isolated from $G$. howii. Yao Хие Хие Ваo 1998;33:493-7.

79. $\mathrm{He} \mathrm{J}, \mathrm{Xu} \mathrm{C}$. Inhibitory effect of Howiinol A(GHM-10) on the synthesis of biological macromolecules in L1210 cells. Үао Хие Хие Bao 1998;33:886-90.

80. He J, Ye Y, Xu C. Antitumor activity of howiinol (GHM-10) on L1210 cells in vitro. Yao Хиe Хие Ваo 1998:33:566-70.

81. Sun S, Yu D. [Studies on the synthesis and antitumour activities of Howiinol A and its analogies. Yао Хие Хие Ваo 1998:33:502-11.

82. Tian Z, Chen S, Zhang Y, Huang M, Shi L, Huang F, Fong C, et al. The cytotoxicity of naturally occurring styryl lactones. Phytomedicine 2006;13:181-6.

83. Zhong L, Li CM, Hao XJ, Lou LG. Induction of leukemia cell apoptosis by cheliensisin A involves down-regulation of $\mathrm{Bcl}-2$ expression. Acta Pharmacol Sin 2005;26:623-8.

84. Wang G, Ahmad KA, Ahmed K. Modulation of death receptormediated apoptosis by CK2. Mol Cell Biochem 2005;274:201-5.

85. Folmer F, Blasius R, Morceau F, Tabudravu J, Dicato M, Jaspars $\mathrm{M}$, et al. Inhibition of $\mathrm{TNF} \alpha$-induced activation of nuclear factor $\mathrm{\kappa B}$ by kava (Piper methysticum) derivatives. Biochem Pharmacol 71:1206-18.

86. Seidel S, Bailleul F, Waterman PG. (Rel)-1 $\beta, 2 \alpha$-di-(2,4-dihydroxy6-methoxybenzoyl)-3 $\beta, \quad 4 \alpha$-di-(4-methoxyphenyl)-cyclobutane and other flavonoids from the aerial parts of G. gardneri and G. thwaitesii. Phytochemistry 2000;55:439-6.

87. Sheng-Teh L, Yang-Chang W, Shiow-Piaw L. Isoquinoline alkaloids of formosan Fissistigma and G. species. Phytochemistry 1985;24:1829-34.

88. Sunil KT, Dipankar B, Pratap C, Bani T. Aristololactams of G. sesquipedalis Wall. Revised structures of the 2-oxygenated aristololactams. Phytochemistry 1988;27:903-6.

89. Soonthornchareonnon N, Suwanborirux K, Bavovada R, Patarapanich C, Cassady JM. New cytotoxic 1-azaanthraquinones and 3-aminonaphthoquinone from the stem bark of G. marcanii. J Nat Prod 1999;62:1390-4.

90. Zhang YJ, Kong M, Chen RY, Yu DQ. Alkaloids from the roots of G. griffithii.. J Nat Prod 1999;62:1050-2.
91. Jantan I, Ahmad F, Ahmad AS. A comparative study of the essential oils of four Goniothalamus species. Bot J Linn Soc 2003; $142: 321$.

92. Siti NMJ, Noor RA, Mohamad KAG, Syed ZSI, Khozirah S, Lokman HS, et al. The screening of extracts from G. scortechinii, Aralidium pinnatifidum and Andrographis paniculata for antimalarial activity using the lactate dehydrogenase assay. J Ethnopharmacol 2002;82:239-242.

93. Harborne JB. Phytochemical Methods. London: Chapman and Hall, 1984.

94. Bauer AW, Kirby WMM, Sherries JC, et al. Antibiotic susceptibility testing by standard single disc diffusion method. Amer $J$ Clin Path 1966;45:426-33.

95. Greenwood D, Slack RCB, Peutherer JF. Medical Microbiology, 15th edn. Edinburgh, UK: Churchill Livingstone, 1997.

96. Gabaldon T, Rainey D, Huynen MA. Tracing the evolution of a large protein complex in the eukaryotes, NADH:ubiquinone oxidoreductase (Complex I). J Mol Biol 2005;348:857-70.

97. Wiart C. Medicinal Plants of Asia and the Pacific. USA: CRC Press, 2006.

98. Wiart C, Hannah A, Yassim M, Hamimah H, Sulaiman M. Antimicrobial activity of Acalypha siamensis Oliv. ex Gage. J Ethnopharmacol 2004;9:285-6.

99. Wiart C, Mogana S, Khalifah S, Mahan M, Ismail S, Buckle M, et al. Antimicrobial screening of plants used for traditional medicine in the state of Perak, Peninsular Malaysia. Fitoterapia 2004;75:68-73.

100. Wiart C, Hannah NA, Yassim M, Hamimah H, Sulaiman M. Antimicrobial activity of tiger's betel (Piper porphyrophyllum N.E. Br., Piperaceae). Phytother Res 2004;18:783-4.

101. Vadillo OF, Avila VMA, Guerrero HC, Arechavaleta VF, Montoya BJ. Apoptosis in trophoblast of patients with recurrent spontaneous abortion of unidentified cause. Ginecol Obstet Mex 2000;68:122-31.

102. Jerzak M, Kasprzycka M, Wierbicki P, Kotarski J, Gorski A. Apoptosis of $\mathrm{T}$ cells in the first trimester human deciduas. C Am J Reprod Immunol 1998;40:130-5.

103. Chan KM, Rajab NF, Ishal MHA, Ali AM, Yusoff K, Din LB, Inayat-Hussain SH. Goniothalamin induces apoptosis in vascular smooth muscle cells. Chem Biol Interact 2005;159:129-40.

104. Tanaka S, Yoichi S, Ao L, Matumoto M, Morimoto K, Akimoto $\mathrm{N}$, et al. Potential immunosuppressive and antiinflammatory activities of Malaysian medicinal plants characterized by reduced cell surface expression of cell adhesion molecules. Phythoter Res 2001;15:681-6.

105. Chinnock P, Siegfried N, Clarke M. Is Evidence-Based Medicine Relevant to the Developing World? Evid-Based Complement Altern Med 2005;2:321-4.

106. Cooper EL. Drug Discovery, CAM and Natural Products. Evid-Based Complement Altern Med 2004;1:215-7.

Received March 15, 2005; accepted January 16, 2007 


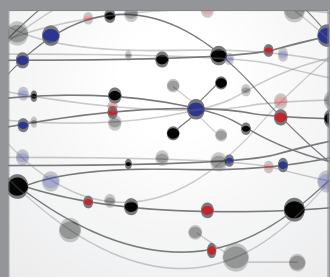

The Scientific World Journal
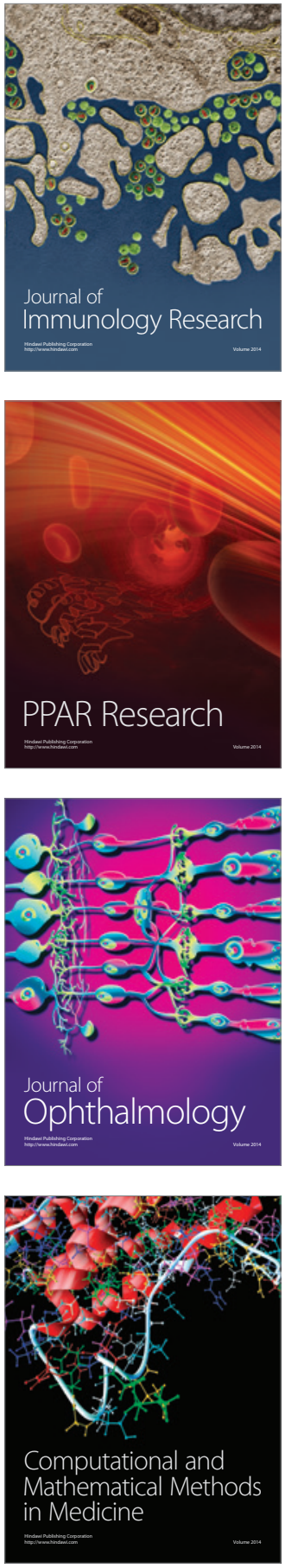

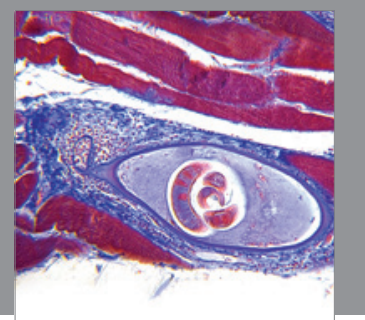

Gastroenterology

Research and Practice
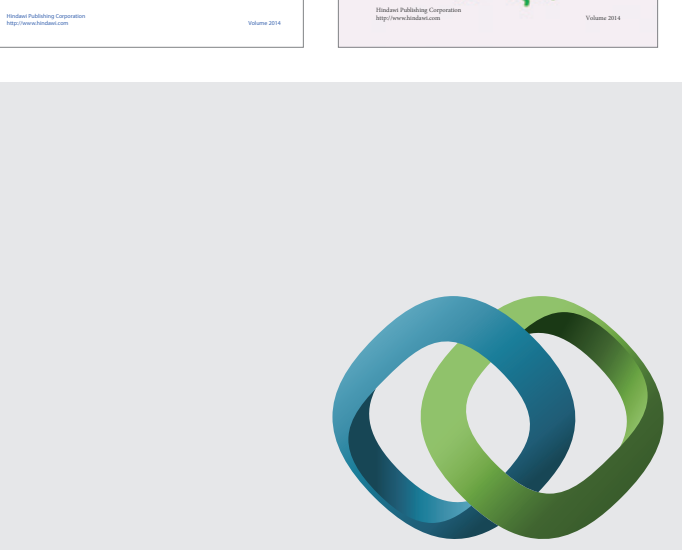

\section{Hindawi}

Submit your manuscripts at

http://www.hindawi.com
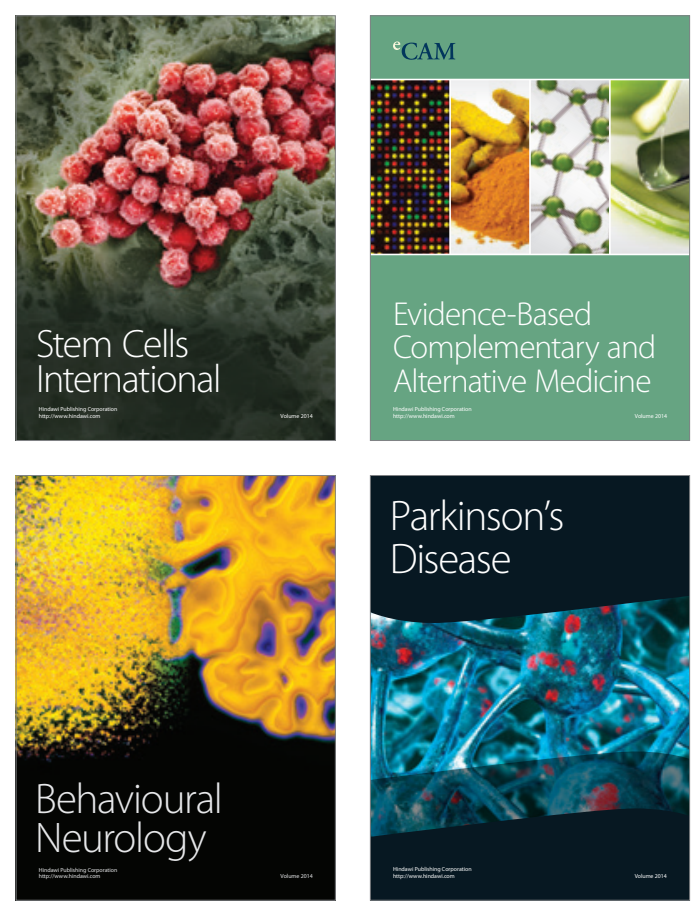

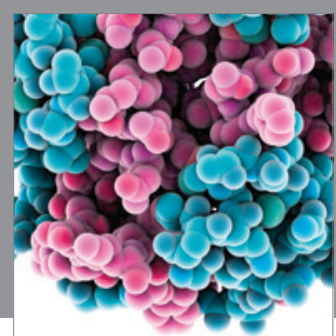

Journal of
Diabetes Research

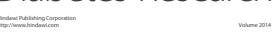

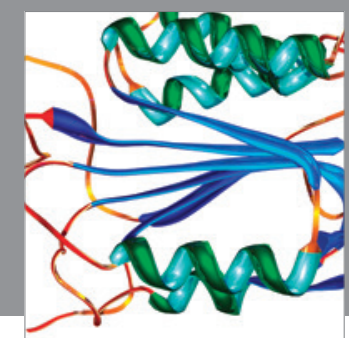

Disease Markers
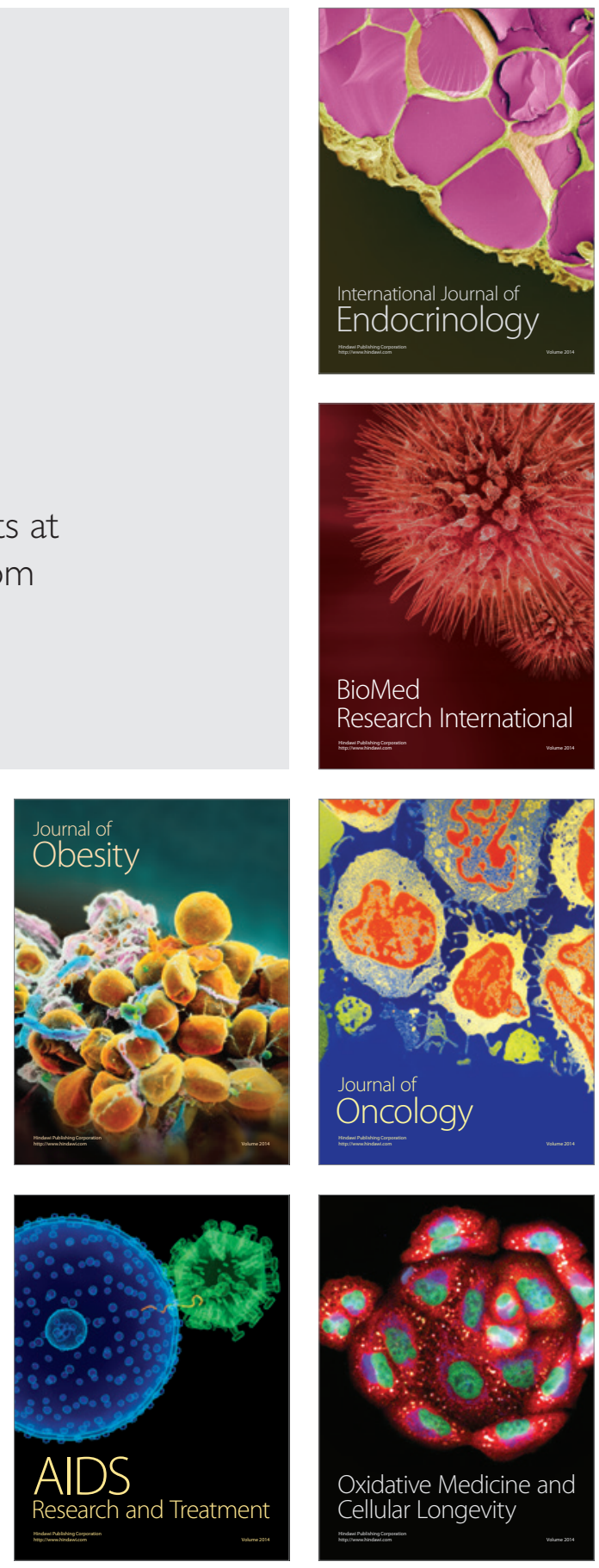